\title{
Energy Recovery routes from Municipal Solid Waste, A case study of Arusha-Tanzania
}

\author{
Arthur Omari $^{1 *}$ Mahir Said ${ }^{2}$ Karoli Njau ${ }^{1}$ Geoffrey John ${ }^{2}$ Peter Mtui ${ }^{2}$ \\ ${ }^{1}$ School of MEWES, The Nelson Mandela African Institution of Science and Technology, \\ P.O. Box 447, Arusha. Tanzania \\ ${ }^{2}$ College of Engineering and Technology, University of Dar es Salaam \\ P.O. Box 35131, Dar es Salaam. Tanzania \\ *E-mail of corresponding author: omaria@nm-aist.ac.tz
}

\begin{abstract}
A study of energy recovery from municipal solid waste was undertaken. The energy content of the solid waste is $12 \mathrm{MJ} / \mathrm{kg}$. The elemental composition shows that the municipal solid waste contains $50 \%$ and $5 \%$ of carbon and hydrogen respectively. The energy flow (exothermic and endothermic) and thermal degradation analysis were carried out using differential scanning calorimetry and thermo-gravimetric analyser respectively. Experiments were performed at heating rate of $10 \mathrm{~K} / \mathrm{min}, 20 \mathrm{~K} / \mathrm{min}, 30 \mathrm{~K} / \mathrm{min}$ and $40 \mathrm{~K} / \mathrm{min}$ in the nitrogen atmosphere at temperature between room temperature and $1273 \mathrm{~K}$. The thermal degradation kinetic parameters values of activation energy ( $\left.E_{a}\right)$ ranged from 205.9 to $260.6 \mathrm{~kJ} / \mathrm{mol}$. It has been observed that municipal solid waste is less reactive to combustion as compared to coal and biomass, but its reactivity can be improved through pre-treating process so as to reduce noncombustible materials such as oxygen and ash content. Also pyrolysis and gasification can be used to convert MSW to liquid or gaseous fuel.
\end{abstract}

Keywords: Municipal Solid Waste, Thermal behavior, Thermo gravimetric Analysis.

\section{Introduction}

Municipal solid waste generation has been in the increase due to population growth, changing lifestyles, technology development and increased consumption of goods. The increase of wastes generation may lead to environmental problems if not properly managed (A. Johari et al., 2012). Urban centers in developing countries are facing a challenge in solid waste management due to population growth and are constrained by lack of an effective recycling of the biodegradable components into useful materials, poor waste management and waste handling infrastructure (R.K. Henry et al., 2006;J.-H. Kuo et al., 2008).

Despite having abundant solid waste in developing countries, these countries are facing energy crisis which pose a challenge to their economic and social development. Combining waste management with waste energy recovery step from municipal solid waste can address the problems of solid waste management and partly the energy crisis. A disposal method using thermal degradation processing could be a better option for the waste management than biogenic methods. This method has advantages, such as substantial reduction in volume and mass. In order to apply the method in a large scale, there are fundamental parameters such as fuel behavior in thermal degradation, energy contents and its chemical reactions that should be in place so as to assist designers to come up with an appropriate method of waste energy recovery and disposal system (M.J. Quina et al., 2008).

In this study, the thermal degradation behavior of municipal solid waste in a growing urban city of Arusha, Tanzania as a case study is undertaken. This includes determination of its proximate analysis, ultimate analysis higher heating value and kinetics.

\section{Material and Methods}

\subsection{Methodology}

The methodology consists of sampling selection, sorting and laboratory analysis to determine the chemical and physical properties of municipal solid waste of Arusha city. The method of sampling was based on ASTM D5231 namely random truck sampling and quatering (A. AbdAlqader and J. Hamad, 2012). In this study the wastes were collected by means of push carts and donkey carts, and were randomly collected from different collecting point of Sakina, Kaloleni and Central market within the Arusha City. The wastes were sorted and weighted by using weighing balance and then separated according to defined classification such as plastics, glass, paper, food waste and metals. The non-combustible wastes were removed from the rest of the wastes. The combustible waste was availed for analysis in accordance to the method developed by (P. McCauley-Bell et al., 1997;G.S. Yang, 2012).

In order accurately to get waste composition an average weight of about $200 \mathrm{~kg}$ of municipal solid waste was taken. The waste was then taken as good representative of the total municipal solid waste composition at each collecting points under this study. The samples were subjected to standards test methods of proximate and ultimate analysis in accordance to ASTMD3172 and ASTM D3176 respectively.

The thermal degradation analysis was studied under Nitrogen condition using a thermo gravimetric analyzer type 
NETZSCH STA 409 PC Luxx connected to power unit 230V, 16A. High purity nitrogen, 99.95\% used as carrier gas controlled by gas flow meter was fed into the thermo gravimetric analyzer with flow rate of $60 \mathrm{ml} / \mathrm{min}$ and a pressure of 0.5 bars. In the STA 409 PC Luxx, proteus software was utilized to acquire, store and analyze the data.

\subsection{Sample preparation}

The samples were shredded into smaller pieces of approximately $30 \mathrm{~mm}$ size, mixed and grounded in a grinding machine to less than $1 \mathrm{~mm}$ size, this is in order to increases surface area of the sample that will allow easier penetration of heat (M.H.M. Yusoff and R. Zakaria, 2012) Then a sample of $30 \pm 0.1 \mathrm{mg}$ with average particle size less than $1 \mathrm{~mm}$ was loaded to crucible and subjected into furnace and heated from 303 to $1273 \mathrm{~K}$ at heating rate of $10 \mathrm{~K} / \mathrm{min}, 20 \mathrm{~K} / \mathrm{min}, 30 \mathrm{~K} / \mathrm{min}$ and $40 \mathrm{~K} / \mathrm{min}$. The heating rate variation changes the peak temperature of the decomposition, as the heating rate increases, the peak temperature also increases (S. Ledakowicz and P. Stolarek, 2003). The calculated thermo-gravimetric output from proteus software was obtained as thermal decomposition profile; thermo-gravimetric (TG), differential thermo-gravimetric (DTG) and differential scanning calorimetry (DSC) curves.

Heat release and absorbed by municipal solid waste degradation was determined by using differential scanning calorimetry curves. The DSC monitors heat effect associated with phase changes transitions and chemical reactions as a function of temperature (R. Huffman and W.-P. Pan, 1990). The heat was determined by calculating the area between the baseline and the curve. The heat can be positive or negative. When the heat is positive the process is endothermic and when the heat is negative the process is exothermic (M. Tettamanti et al., 1998)

\subsection{The kinetic parameter.}

The kinetic parameter was determined by using Kissinger's method. This is used as a standard method for studying the thermal degradation of municipal solid waste under non isothermal condition (S. Ledakowicz and P. Stolarek, 2003). The rate constant is expressed by Arrhenius Equation (1) where, $\mathrm{k}$ is the rate constant, which is temperature dependent (T. Sonobe and N. Worasuwannarak, 2008).

$$
\begin{gathered}
k=A \exp \left(-E_{a} / R T\right) \\
d x / d t=A f(x) \exp \left(-E_{a} / R T\right) \\
x=\left(w_{0}-w_{t}\right) /\left(w_{0}-w_{\infty}\right)
\end{gathered}
$$

where, $\mathrm{x}$ is the reacted fraction, $\mathrm{w}_{0}$ the initial mass, $\mathrm{w}_{\mathrm{t}}$ the mass remaining at time $\mathrm{t}, \mathrm{w}_{\infty}$ the final mass, $\mathrm{T}$ the absolute temperature, $E_{a}$ the activation energy, A the pre-exponential factor, $R$ the universal gas constant and $f(x)$ the algebraic function depending on the reaction mechanism. The temperature rise at a constant heating rate $(\beta)$ is expressed as shown in Equation 4.

$$
\beta=d T / d t
$$

Equation 5 is a result of differentiation of Equation 2

$$
d^{2} x / d t=\left\{E_{a} \beta / R T^{2}+A f^{\prime}(x) \exp \left(-E_{a} / R T\right)\right\} d x / d t
$$

The maximum rate occurs at a temperature $\mathrm{T}_{\text {peak }}$; approximations at $\mathrm{T}_{\text {peak }}$ condition yield Equation 6.

$$
\ln \left(\beta / T_{\text {peak }}^{2}\right)=\ln \left(A R / E_{a}\right)-\left(E_{a} / R T_{\text {peak }}\right)
$$

Equation 6 is a straight line graph, of $\ln \left(\beta / T^{2}{ }_{\text {peak }}\right) v / s\left(1 / T_{\text {peak }}\right)$, The line slope is $E_{a} / R$ and the intercept on the vertical axis is $\ln \left(\mathrm{AR} / \mathrm{E}_{\mathrm{a}}\right)$, which are used to determine the values of $\mathrm{E}_{\mathrm{a}}$ and $\mathrm{A}$.

The fractional pyrolysis of municipal solid waste component is obtained by taking the ratio of the change mass of municipal solid waste component at time $t$ and total reactive mass of a sample as shown in Equation 3. 


\section{Results and Discussion}

\subsection{Proximate and ultimate analysis}

The results of proximate and ultimate analysis are shown in Table 1. The moisture content of the municipal solid waste as received ranges between 55.70 and 63.99 wt. \%, which is more than $50 \mathrm{wt}$. \% of the total weight of the sample. This high moisture content is prohibitive for combustion process as it rises the ignition temperature, also its contents reduces the calorific value of the fuel (M. Muthuraman et al., 2010), the moisture could be reduced by drying. The volatiles released on dry basis of MSW for Kaloleni, Sakina and Central market are 74.43, 84.00 and $78.31 \mathrm{wt} . \%$, respectively, whilst the volatile matter contained in pure biomass such as forest residue, oak wood, and pine are 79.9, 78.1 and 83.1 wt. \% respectively (S.V. Vassilev et al., 2010). Generally, fuels that contains high volatile, have low fixed carbon, the case is same for the municipal solid waste from Kaloleni which has fixed carbon of about $17 \mathrm{wt}$ \%, which is higher than that of Sakina and Central market. The advantage of high volatile and low fixed carbon is rapid burning of a fuel, while a fuel with low volatile and high fixed carbon like coal need to be burn on a grate as it take long time to burn out, unless it is pulverized to a very small size (P. McKendry, 2002) Therefore the value of volatile matter and fixed carbon shows that the municipal solid waste is combustible. The ash range between 3.29 to $5.97 \mathrm{wt}$ \% , which is small, this is advantage to waste management and environment because the possibility of having small quantity of heavy metals, salts, chlorine and organic pollutant is small (C.H. Lam et al., 2010). The ultimate analysis of the municipal solid waste shows that the concentration of phosphorus and chlorine are negligible, the carbon and hydrogen content were above $50 \%$ and $5 \%$ respectively. The oxygen content was more than $34 \%$. Sulfur is about $0.29 \%$, this is low compared to values from 1.1 wt. \% of bituminous coal analysis (T. Nakao et al., 2006).

Table 1: Proximate, ultimate analysis and HHV of Arusha municipal solid waste

\begin{tabular}{|c|c|c|c|c|c|c|c|c|}
\hline & \multicolumn{8}{|c|}{ Proximate analysis } \\
\hline Location & \multicolumn{2}{|c|}{$\begin{array}{l}\text { Moisture of } \\
\text { received } \\
\text { MSW (wt. \%) }\end{array}$} & \multicolumn{2}{|c|}{$\begin{array}{c}\text { Volatile } \\
\text { (wt.\%) dry } \\
\text { basis }\end{array}$} & $\begin{array}{c}\text { Ash } \\
\text { (wt. \%) dry } \\
\text { basis }\end{array}$ & \multicolumn{2}{|c|}{$\begin{array}{l}\text { Fixed carbon } \\
\text { (wt. \%) dry } \\
\text { basis }\end{array}$} & $\begin{array}{c}\text { HHV } \\
(\mathrm{MJ} / \mathrm{kg})\end{array}$ \\
\hline Kaloleni & \multicolumn{2}{|l|}{59.67} & \multicolumn{2}{|c|}{74.43} & 8.16 & \multicolumn{2}{|c|}{17.41} & 11.90 \\
\hline Sakina & \multicolumn{2}{|l|}{63.99} & \multicolumn{2}{|c|}{84.00} & 10.00 & \multicolumn{2}{|c|}{6.00} & 11.37 \\
\hline \multirow[t]{2}{*}{ Central market } & 55.70 & & \multicolumn{2}{|c|}{78.30} & 13.48 & \multicolumn{2}{|c|}{8.22} & 12.76 \\
\hline & \multicolumn{8}{|c|}{ Ultimate analysis } \\
\hline Location & $\begin{array}{c}\mathrm{C} \\
\text { (wt. \%) }\end{array}$ & & $\begin{array}{l}\mathrm{H} \\
\text { t. } \%)\end{array}$ & $\begin{array}{c}\mathrm{O} \\
\text { (wt. \%.) }\end{array}$ & $\begin{array}{c}\mathrm{N} \\
\text { (wt. \%) }\end{array}$ & $\begin{array}{c}\mathrm{S} \\
\text { (wt. \%) }\end{array}$ & $\begin{array}{r}\mathrm{C} \\
\text { (wt. }\end{array}$ & $\begin{array}{c}\mathrm{P} \\
\text { (wt. \%) }\end{array}$ \\
\hline Kaloleni & 55.57 & & 5.34 & 34.88 & 2.09 & 0.31 & 0.0 & 0.10 \\
\hline Sakina & 55.70 & & 5.29 & 34.27 & 2.13 & 0.22 & 0.0 & 0.13 \\
\hline Central Market & 53.20 & & 5.24 & 34.71 & 2.86 & 0.37 & 0.0 & 0.11 \\
\hline
\end{tabular}

\subsection{Calorific value}

The municipal solid waste calorific value is about $12 \mathrm{MJ} / \mathrm{kg}$. This value is smaller than average biomass heating value of about $17 \mathrm{MJ} / \mathrm{kg}$ (F. Heylighen, 2001) This means energy release during combustion of MSW is smaller compared to biomass combustion. This means that one needs to burn larger amount of MSW to get the same amount of energy. The energy content of MSW can be improved by pre-treating the MSW so as to reduce oxygen amount, since oxygen reduces the energy content of a fuel (P. McKendry, 2002). The MSW can be cofired with coal for improving energy content (M. Sami et al., 2001;Z. Li et al., 2004). Other processes to improve energy content of MSW are pyrolysis, gasification or torrefaction, these are used to produce bio-oil, syngas or char respectively.

The municipal solid waste from all collecting points degraded to 75 to $85 \mathrm{wt}$ \% in the thermo gravimetric analyser as shown in Figure 1. The MSW from Central market degraded by 85 wt. \%, while the Kaloleni degraded by $75 \mathrm{wt}$. \%. The residue formed is between 25 and $15 \mathrm{wt}$. \%. The residue contains fixed carbon and ash, the high residue is observed at MSW from Kaloleni (25 wt. \%) and the lowest residue is observed at MSW from Central market and Sakina $15 \mathrm{wt}$. \%. The char can be used as a fuel, but MSWs that have high ash content hinder the combustion of char due to the layer of ash formed on the surface it inhibited the diffusion of oxygen into the char (D.A. Himawanto et al., 2013). 


\subsection{DTG curves}

Figure 2 shows the derivative of thermo-gravimetric analysis (DTG), which has four visible regions; these are moisture release region, lignocellulosic degradation region, plastic degradation region and char pyrolysis region (Z. Lai et al., 2011).

The moisture release region is ranging between 303 and 423. Lignocellulosic degradation region ranges between 423 and $643 \mathrm{~K}$, at these region volatile matters are released; the region corresponds to pyrolysis of lignocellulosic biomass. The plastic degradation ranges between 643 and $913 \mathrm{~K}$ and the char pyrolysis region ranges between 913 and 1273. The same identified regions were also observed by Lai et al., (2011).

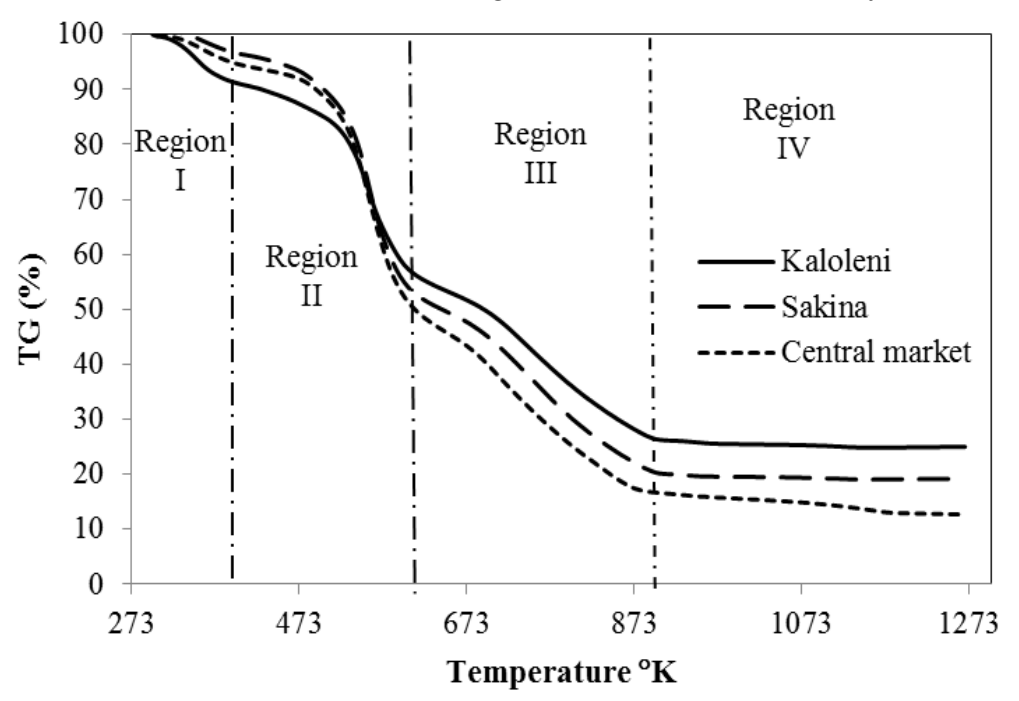

Figure 1: TG of Municipal solid waste

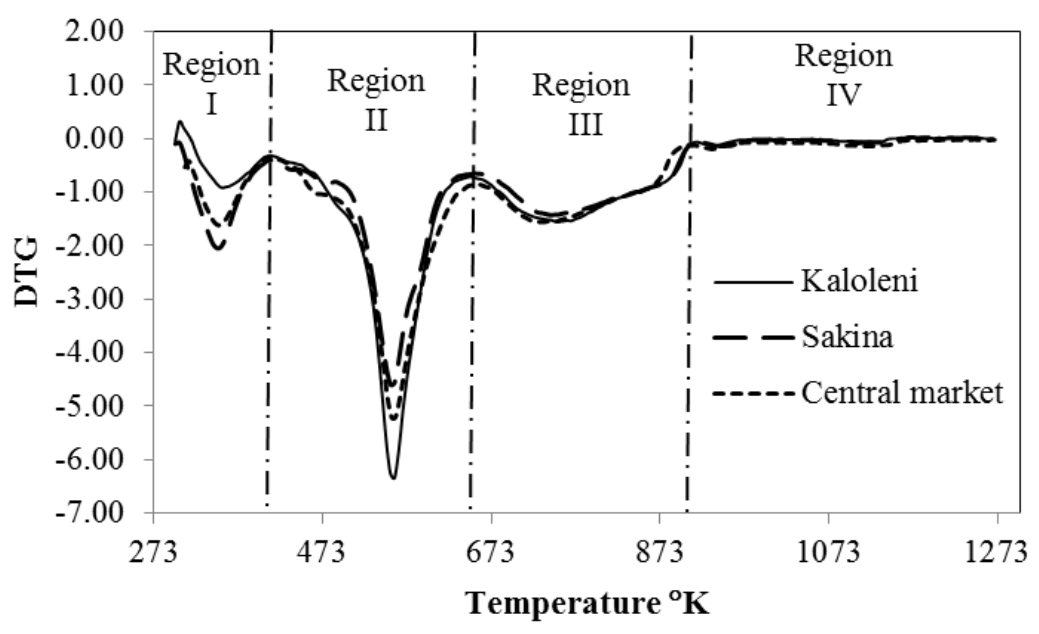

Figure 2: DTG of municipal solid waste

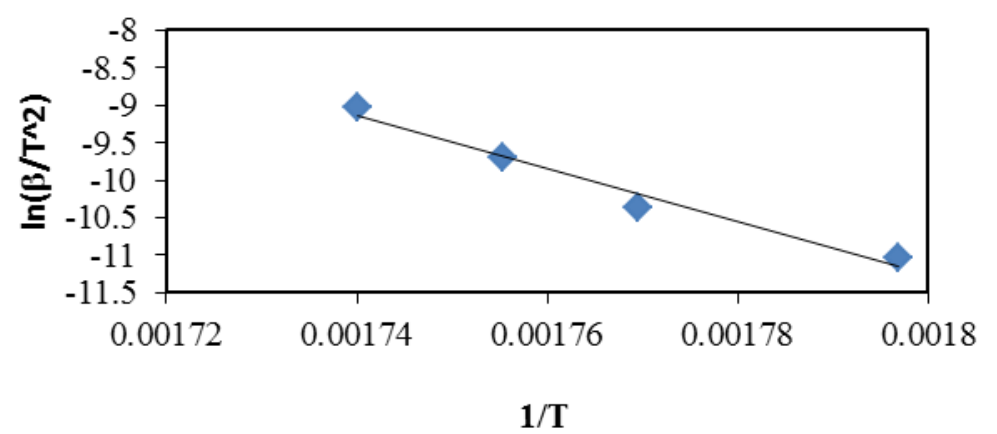

Figure 3: Determination of kinetic parameter of Arusha municipal solid waste. 
DTG curves at different heating rate were used to develop Figure 3, which was used to calculate the activation energy (Ea) and pre exponential factor (A), as given in Table 2. The activation energy of MSW ranged between $205.934 \mathrm{~kJ} / \mathrm{mol}$ and $260.60 \mathrm{~kJ} / \mathrm{mol}$. This value is higher than that of biomass and coal which range between 50 and $180 \mathrm{~kJ} / \mathrm{mol}$ and 30 and $90 \mathrm{~kJ} / \mathrm{mol}$ respectively. This corresponds to the biomass of cypress wood chips and macadamia nut shells as observed by Vhathvarothai et al. (2013), that the value was $168.7 \mathrm{~kJ} / \mathrm{mol}$ and $164.5 \mathrm{~kJ} / \mathrm{mol}$ respectively (N. Vhathvarothai et al., 2013). This shows that MSW need high energy to react as compared to biomass and coal. The reactivity of MSW can be increased by reducing the noncombustible material such as oxygen and also to remove volatile material, these can be done by pretreating the material through torrefaction process (A.K. Biswas, 2011).

Table 2 Activation energy and Pre-exponential factor of municipal solid waste

\subsection{DSC curves}

\begin{tabular}{|l|l|l|}
\hline Location & $\mathrm{E}_{\mathrm{a}}(\mathrm{kJ} / \mathrm{mol})$ & $\mathrm{A}\left(\mathrm{s}^{-1}\right)$ \\
\hline Kaloleni & 258.680 & $9.142 \times 1023$ \\
\hline Sakina & 205.934 & $8.977 \times 1018$ \\
\hline Central Market & 260.60 & $1.186 \times 1028$ \\
\hline
\end{tabular}

The differential scanning calorimetry (DSC) curves shown in Figure 4, reveal endothermicity between 303 and 423 , this is due to evaporation of moisture. In the temperature range of 423 to $1273 \mathrm{~K}$ the process undergoes exothermic reaction due to the devolatilization of the municipal solid waste and plastic pyrolysis. The energy absorbed due to evaporation of moisture for wastes from Kaloleni, Sakina and Central market collecting points were $0.11 \mathrm{MJ} / \mathrm{kg}, 0.20 \mathrm{MJ} / \mathrm{kg}$ and $0.15 \mathrm{MJ} / \mathrm{kg}$ respectively, whilst energy released from the same respective collection points were $-7.6 \mathrm{MJ} / \mathrm{kg},-8.3 \mathrm{MJ} / \mathrm{kg}$ and $-8.5 \mathrm{MJ} / \mathrm{kg}$ in respective manner. The energy released in the DSC by municipal solid waste was lower than higher heating value $(12.54 \mathrm{MJ} / \mathrm{kg})$. This is because the DSC used nitrogen as heating media while in bomb calorimeter oxygen is applied for combustion.

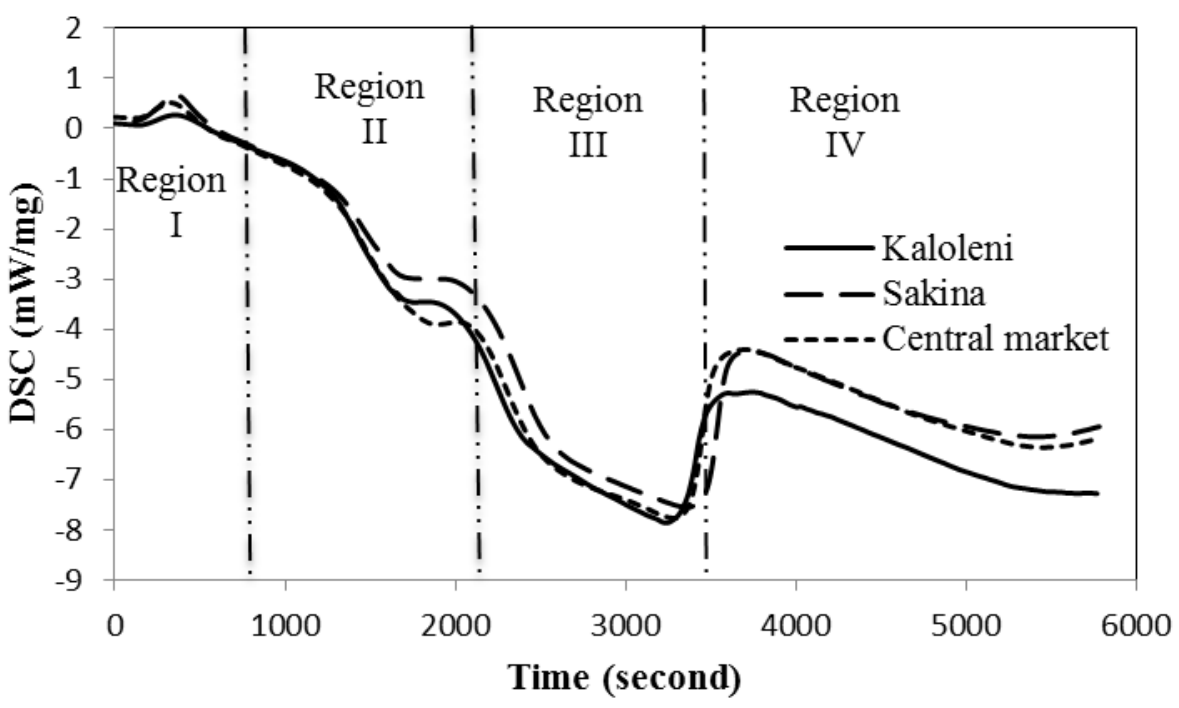

Figure 4: DSC of Arusha Municipal solid waste sites.

\section{Conclusion}

This paper presents finding related to municipal solid waste characterization of Arusha city. The proximate analysis of municipal solid waste show that, the waste contains more than $50 \%$ and $5 \%$ of carbon and hydrogen respectively which may contribute to high calorific value of Arusha municipal solid waste. The ultimate analysis shows that average amount of nitrogen, sulfur, chlorine and phosphorus are small, these reduce emissions during combustion.

The energy content of waste determined by bomb calorimeter is about $12 \mathrm{MJ} / \mathrm{kg}$ this is about $30 \%$ of energy containing in coal and $60 \%$ of energy containing in biomass. The activation energy was ranging between 205.9 and $260.6 \mathrm{~kJ} / \mathrm{mol}$. The municipal solid waste shows exothemicity property at the devolatilization zone. The 
devolatization zone shows that the municipal solid waste can be easily ignited at temperature above $423 \mathrm{~K}$. Therefore municipal solid waste has a good potential to be used as a fuel.

\section{Acknowledgements}

The authors wish to thank the NM AIST and COSTECH for sponsoring of this research, Arusha city council for allowing us to use their facility during waste characterization, the laboratory of Energy of the University of Dar es Salaam for allowing utilization of their laboratory for waste analysis.

\section{List of Abbreviation}

$\begin{array}{lc}\text { ASTM } & \text { American Standard Test and Methods } \\ \text { COSTECH } & \text { Commission for Science and Technology } \\ \text { DSC } & \text { Differential scanning calorimetry } \\ \text { DTG } & \text { Differential thermal gravimetric } \\ \text { HHV } & \text { Higher heating values } \\ \text { NM AIST } & \text { Nelson Mandela African Institute of Science and Technology } \\ \text { TG } & \text { Thermal gravimetric analysis } \\ \text { UDSM } & \text { University of Dar es Salaam }\end{array}$

\section{References}

AbdAlqader, A. and Hamad, J. (2012). Municipal solid waste composition determination supporting the integrated solid waste management in Gaza strip. Int. J. Environ. Sci. Dev. 3(2): 172-177.

ASTM D3172-07 in Standard Practice for Proximate Analysis of Coal and Coke. West Conshohocken, PA: 19428-2959.

ASTM D3176-89 in Standard Test Method for Ultimate Analysis of Coal and Coke. ASTM International, West Conshohocken, PA.

Biswas, A.K. (2011). Thermochemical behavior of pretreated biomass.

Henry, R.K., Yongsheng, Z. and Jun, D. (2006). Municipal solid waste management challenges in developing countries - Kenyan case study. Waste Management. 26(1): 92-100.

Heylighen, F. (2001). Encyclopedia of Life Support Systems.

Himawanto, D.A., Saptoadi, H. and Rohmat, T.A. (2013). Thermogravimetric Analysis of Single-Particle RDF Combustion. Modern Applied Science. 7(11).

Huffman, R. and Pan, W.-P. (1990). Combining DSC and TG data for measuring heats of reaction. Thermochimica acta. 166(251-265.

Johari, A., Hashim, H., Mat, R., Alias, H., Hassim, M. and Rozzainee, M. (2012). Generalization, formulation and heat contents of simulated MSW with high moisture content. Journal of Engineering Science and Technology. 7(6): 701-710.

Kuo, J.-H., Tseng, H.-H., Rao, P.S. and Wey, M.-Y. (2008). The prospect and development of incinerators for municipal solid waste treatment and characteristics of their pollutants in Taiwan. Applied Thermal Engineering. 28(17): 2305-2314.

Lai, Z., Ma, X., Tang, Y. and Lin, H. (2011). A study on municipal solid waste (MSW) combustion in N2/O2 and $\mathrm{CO} 2 / \mathrm{O} 2$ atmosphere from the perspective of TGA. Energy. 36(2): 819-824.

Lam, C.H., Ip, A.W., Barford, J.P. and McKay, G. (2010). Use of incineration MSW ash: A review. Sustainability. 2(7): 1943-1968.

Ledakowicz, S. and Stolarek, P. (2003). Kinetics of biomass thermal decomposition. Chemical papers - slovak Academic of Science. 56(6): 378-381.

Li, Z., Lu, Q. and Na, Y. (2004). $\mathrm{N}_{2} \mathrm{O}$ and NO emissions from co-firing MSW with coals in pilot scale CFBC. Fuel Processing Technology. 85(14): 1539-1549.

McCauley-Bell, P., Reinhart, D.R., Sfeir, H. and Ryan, B.O.T. (1997). Municipal solid waste composition studies. Practice Periodical of Hazardous, Toxic, and Radioactive Waste Management. 1(4): 158-163.

McKendry, P. (2002). Energy production from biomass (part 1): overview of biomass. Bioresource Technology. 83(1): 37-46.

Muthuraman, M., Namioka, T. and Yoshikawa, K. (2010). A comparative study on co-combustion performance 
of municipal solid waste and Indonesian coal with high ash Indian coal: A thermogravimetric analysis. Fuel Processing Technology. 91(5): 550-558.

Nakao, T., Aozasa, O., Ohta, S. and Miyata, H. (2006). Formation of toxic chemicals including dioxin-related compounds by combustion from a small home waste incinerator. Chemosphere. 62(3): 459-468.

Quina, M.J., Santos, R.C., Bordado, J.C. and Quinta-Ferreira, R.M. (2008). Characterization of air pollution control residues produced in a municipal solid waste incinerator in Portugal. Journal of Hazardous Materials. 152(2): 853-869.

Sami, M., Annamalai, K. and Wooldridge, M. (2001). Co-firing of coal and biomass fuel blends. Progress in Energy and Combustion Science. 27(2): 171-214.

Sonobe, T. and Worasuwannarak, N. (2008). Kinetic analyses of biomass pyrolysis using the distributed activation energy model. Fuel. 87(3): 414-421.

Tettamanti, M., Collina, E., Lasagni, M., Pitea, D., Grasso, D. and La Rosa, C. (1998). Characterization of fly ash from municipal solid waste incinerators using differential scanning calorimetry. Thermochimica acta. 321(1): 133-141.

Vassilev, S.V., Baxter, D., Andersen, L.K. and Vassileva, C.G. (2010). An overview of the chemical composition of biomass. Fuel. 89(5): 913-933.

Vhathvarothai, N., Ness, J. and Yu, Q.J. (2013). An investigation of thermal behaviour of biomass and coal during copyrolysis using thermogravimetric analysis. International Journal of Energy Research.

Yang, G.S. (2012). Identification of the Municipal Solid Waste Characteristics and Potential of Plastic Recovery at Bakri Landfill, Muar, Malaysia. Journal of Sustainable Development. 5(7).

Yusoff, M.H.M. and Zakaria, R. (2012). Combustion of Municipal Solid Waste in Fixed Bed Combustor for Energy Recovery. Journal of Applied Sciences. 12(11). 
The IISTE is a pioneer in the Open-Access hosting service and academic event management. The aim of the firm is Accelerating Global Knowledge Sharing.

More information about the firm can be found on the homepage:

http://www.iiste.org

\section{CALL FOR JOURNAL PAPERS}

There are more than 30 peer-reviewed academic journals hosted under the hosting platform.

Prospective authors of journals can find the submission instruction on the following page: http://www.iiste.org/journals/ All the journals articles are available online to the readers all over the world without financial, legal, or technical barriers other than those inseparable from gaining access to the internet itself. Paper version of the journals is also available upon request of readers and authors.

\section{MORE RESOURCES}

Book publication information: http://www.iiste.org/book/

Recent conferences: http://www.iiste.org/conference/

\section{IISTE Knowledge Sharing Partners}

EBSCO, Index Copernicus, Ulrich's Periodicals Directory, JournalTOCS, PKP Open Archives Harvester, Bielefeld Academic Search Engine, Elektronische Zeitschriftenbibliothek EZB, Open J-Gate, OCLC WorldCat, Universe Digtial Library, NewJour, Google Scholar

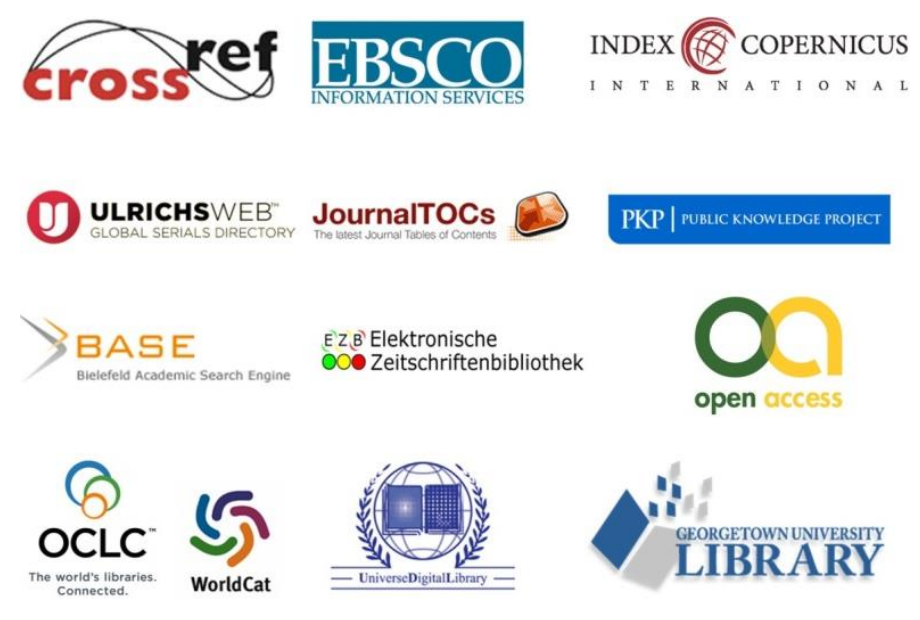

